\title{
Integrity Advisors and the Development of Administrative Communication Culture
}

\author{
Balázs Hohmann J.D. \\ Assistant Lecturer, University of Pécs (Hungary), Faculty of Law President, \\ Consciously for Our Environment Association (Pécs, Hungary)
}

\begin{abstract}
The integrity advisers are the central actors of integrity management systems of the administrative organizational structure, whose main task is to promote the implementation of the integrity approach within state administration institutions. As a complementary part of this task, we can separate the tasks of corruption prevention and the improvement of organizational integrity, of which the latter being discussed in more detail in this research and presentation. Integrity advisers play a key role in the development of organizational culture among public administration bodies, such as bodies exercising administrative authority. Looking at the topic more closely, with regard to the activities of integrity advisers, it can be clearly established that one of the engines of their operation is the proper and deep communication, which is not only necessary within the public administration and interagency transactions, but it also means communication activities that can be interpreted in the relationship between the public and clients. Equally important is their training and other activities aimed at developing staff awareness, relationships, situation assessment and action practices, which, in addition to and in part within public service training, provide an opportunity to shape organizational culture. The presentation and the paper aims to show the role of integrity advisors in developing organizational culture and transparency in the administration based on recent research experience about online presence of integrity advisors and in-depth interview surveys.
\end{abstract}

Keywords: administrative procedure, integrity advisor, organizational culture, transparency.

\section{Introduction}

It was not an easy situation for the public administration at the end of the 20th century and at the beginning of the 21st century interpreted worldwide. While a large-scale flow (Akaike, 1998, pp. 199-213) - almost flood (Cover \& Thomas, 2012; Gray, 2011) - of information as a global process has begun and continues to evolve in many areas of social life, public administration and, in many cases, administrative proceedings still reflect the traditional approach that has been developed earlier. In this approach, such expressions seem novel and maybe even system stranger, as new media administrative proceedings (Józsa, 2013), taking place with the help of social media content (Bertot et. al., 2010, pp. 264-271; Roblyer et. al., 2010, pp. 134-140; Bertot, 2012, pp. 30-40.), SMS (L. László \& Vég, 2004, pp. 1-16), email and other electronic communication channels (Von Haldenwang, 2004, pp. 417-432), and the use and exploitation of big data in an administrative environment (Cheng \& Zhang, 2014, pp. 314-347).

In this article, we would like to reveal that what kinds of requirements for communication in the 21st century are towards each public administration bodies, and what kind of activities and measures it can take to meet this requirement, in particular the activities carried out by integrity advisors and their role in communication.

If these requirements can be clarified, it may also become clear what tasks and requirements can be claimed against the integrity adviser and other persons involved in the communication of the public administration body.

\section{CHARACTERISTICS OF OPEN COMMUNICATION}

In order to be able to interpret the requirements and conditions of the openness of the communication with respect to the system of public administration and its individual bodies, first the open communication and its conceptual elements must be determined and defined. From the point of view of this study, this issue should be clearly examined at organizational 
level, as the body, which is the smallest element of the public administrative organization system, will ultimately mean the overall performance of the communication on the subject (Kuhn et. al., 2018), in relation to which its openness can be assessed. However, the nature and attitude of communication at institutional/organizational level above and below of this is not negligible: neither the organizational structure of the public administration body nor its organizational units and, ultimately, the personal communication (Karanges et al., 2015, pp. 129-131). The major systems of public administration (Bellamy \& Taylor, 1992, pp. 29-41) leave the organizational communication unaffected, they may have a significant effect on it, or at least they can affect its effects and judgment during the interaction with the public administration clients.

The organizational communication with open nature can be circumscribed by the following features based on literature references:

Known roles - All actors in the communication process (sender, receiver, mediator) are aware of their role and the purpose for which they receive the information (Kramer, 2014, pp. 33-50; King et al., 1998, pp. 317-326). This sounds quite simple from a theoretical point of view, but most often in communication situations occurring in practical life, it causes most of the problems (Atouba et. al., 2016; Braun et. al., 2018, pp. 50-81) and leads to undermining openness, laying the ground for mistrust and certain information disruptions that can lead to opacity of activity. In the case of integrity advisors, this means that the integrity advisor, the supreme head of the body, and the heads of the particular organizational units of the body must have appropriate knowledge of the tasks, responsibilities, and powers of the advisors. They must also be able to apply all these simultaneously in practice, so that clients on the other side of the administrative relationship, or other subordinated, coordinated, or superior bodies, can receive appropriate information, or can claim, unlike their role, to transpose the integrity approach and the integrity management, the integrity consultant's results, or vice versa, and can properly make announcements, signs and comments related to these.

Appropriate communication interfaces and opportunities (Ricciardi, 2016, pp. 51-71) - Communication channels and access to them on both sides have a non-negligible role to play. If the communication interface or the unlimited access to the interface in the broad sense is inadequate in relation to the subject of communication and the relationship between the persons involved in communication, communication is not expected to be effective or transparent to organizational processes. Today, electronic technology has a major role to play in this (Middleton et. al., 2017, pp. 105-140; Venkatesh et. al., 2016, pp. 871-111): there is a clear expectation on the part of the public administration that almost all of its services should be made available immediately and, as far as possible, unrestrictedly within the circle where it can be interpreted. In a narrower sense, our focus aims this: on the electronic communication interface, how information related to the integrity advisor's task can appear and be displayed in the online space.

Confidentiality - Open communication can only be expected with good trust between the communicating parties. If the above conditions are met, and the parties know what their roles are and on what kind of interfaces they can interact with each other, then trust can be created (King et. al., 1998, pp. 323-326; Hohmann, 2018, pp. 7-9; Menzel, 2015, pp. 343347; Nisbet, 2009, pp. 12-23); however, it is a fragile state (Nabatchi, 2012, pp. 699-708) and its maintenance is extremely resource intensive (Frederichson \& Rohr, 2015, pp. 25-55). A new dimension of confidentiality needs to be created in the electronic environment (Venkatesh et. al, 2016, pp. 100-111), due to the widespread data management, the disappearance of physical communication between individuals, or falling into the background, which can be a serious task for the public administration. In the area of integrity, trust is of paramount importance: building and maintaining trust is one of the key competencies of an integrity advisor (Becker, 1998, pp.154-161; Butler \& Cantrell, 1984, pp.19-28; Hosmer, 1995, pp. 379403), so a full function can only be filled in such circumstances. This approach should also prevail in creating content and communication opportunities published in the online environment.

Interpretability, clarity - Communication does not become open even if the above parameters are optimally matched, if one or more actors in the communication do not understand - either fully or partly - the content of the message coming in their direction (Ljungholm, 2015, p. 172; Lourenco, 2015, pp. 323-332). Unclear, incomprehensible professional content makes the transparency of the process impossible for the recipient (Ljungholm, 2015, pp. 172-175) and it also has a negative impact on the desired effects of a message (e.g. an administrative decision or a notice issued by an administrative body), to fulfil legal obligations (Durant \& Durant, 2017, pp. 120-150). This must also be true for content published online in the field of integrity.

Traceability (De Nicola et. al., 2016, pp. 18-27) - The parties involved in the communication can fully open up their communication with each other if it becomes accessible and traceable in some form, thus ensuring the traceability and 
recoverability of the information contained in the communication. This is also needed in the integrity advisory role, as a trust-building (Denhardt \& Denhardt, 2000, pp. 549-559) communication towards both internal and external stakeholders must be carried out.

Consistency (Kramer, 2014, pp. 75-90) - Finally, one of the most important features of open communication is that it becomes truly open only if the parties can legitimately count on that the expected and intended results of the communication will occur, because the communication agents carry out their activities according to specific policy principles and they communicate accordingly. Under the rule of law conditions, this is obviously organized around service administration and client orientation, thus communication must also enforce transparency requirements.

\section{AREAS OF ADMINISTRATIVE COMMUNICATION}

\section{COMMUNICATION IN ADMINISTRATIVE PROCEEDINGS}

Openness, client orientation and efficiency (Ostrom \& Ostrom, 1971, pp. 203-216; Hood, 1991, pp. 3-19; Lan \& Rosenbloom, 1992, pp. 535-537) have been expected from public administration by the scientific community, government representatives and citizens for decades. There can be many forms of open character, but in summary we can characterize the legal institutions, procedural law solutions as making the information related to the administrative proceedings more widely available and secured, in addition to protect clients from unauthorized access to their data in individual cases and maintaining the security of administrative decision-making.

From the point of view of management, the topic of integrity is particularly important because it provides input information during the integrity advisor's work and the effective, transparent communication within the main field of administrative law enforcement can be considered as an objective. These opportunities simultaneously fulfil the tasks of the administration, application of the law related to regulatory bodies, they ensure that members of society and organizations can have the opportunity to have a greater social control as playing a greater role in society, they serve the legitimate interests of the clients of the proceedings and other actors and, in addition, they ensure the implementation of modern data and personality protection as expected from the administrative proceedings.

In order to achieve an effective process in the material sense, the authorities nowadays need to pay more attention to stimulating communication (Kettl, 2015) with their clients and other stakeholders. In many cases, the relative closeness of the procedural law solutions and their resulting rigidity can be resolved - of course, in the context of rule of law guarantees and legal framework - in the analysis of legal science and the implementation of the results into practice.

The availability of documents generated during the administrative proceedings, the empowerment of non-governmental organizations having entitlement to represent social groups, the diversification of decision-making forms and the publicity of certain types of special administrative proceedings (e.g. administrative control) may help certain authorities to make the most appropriate decision within the legal framework and to serve its implementation at a higher level. The publicity and transparency of the administrative proceedings do not prima facie belong to the group of mainstream scientific investigations related to public administration and, in particular, the administrative proceedings, which can be traced back to the nature and characteristics of governmental and administrative transparency as nuanced (Meier, 2013, pp. 429-439).

For decades, the administration itself has approached the subject in relative closure. In the period of law enforcement-type administration (Fábián, 2016, pp. 25-45) the constellation would have been unthinkable according to which the public administration, which performs almost all public authority functions, should take into account the aspects of legal entities still in their subject status - now clients - and strive for a consensual solution, either among the persons involved in the proceedings or between such persons and public authorities.

The administration application of this topic, it was necessary to make a fundamental change in the methodology of exercising public authority related to administrative proceedings (Ivancsics \& Fábián, 2018, pp. 32-54). As a result, particular public administration systems have not always approached clients from their original position of power in a conceptual way, and less felt the need to achieve the implementation and protection of the public interest identified as a basic function of public administration - either by legal or other, physical - means of coercion. However, they needed a historically relatively long period of time (Rosenbloom \& Goldman, 1993), to become a client-orientated law enforcement agency, and to explore novel ideas and apply them in practice (Bingham et. al, 2005, pp. 547-558) such as governance (Kettl, 2015, pp. 62-75) and its impact. 
Looking closer at the issue of transparency, it is a highly complex (Meier, 2013, p. 431), category of interdependence with many factors. The examination of transparency, including the transparency of the administrative proceedings on the international scientific scene, and thanks to this, unified modelling on the subject is further complicated by the fact that administrative proceedings have a number of unique characteristics depending on their country-specific legislation and the framework of the administrative proceedings, which may have a decisive influence on the publicity parameters of the proceedings.

In general, if we want to grasp the concept of transparency in general within the framework of the administrative proceedings - in line with the views of the authors mentioned above - then we can define it as a category of administrative procedural rules of the investigated country, the practice of law enforcement - if it exists in a separate form - the practice of administrative courts, and overall, it describes government measures and their social implications for the administration as a whole, depending on the extent to which they serve or restrict access to the public authorities in a broad sense.

\section{HORIZONTAL CRITERION}

The publicity of the administrative proceedings and the communication channels required to do so, can basically be defined as a legal institution of a horizontal nature beyond the above. Its horizontal character is primarily due to the publicity and transparency, as well as the requirements of the legal policy and dogmatic approaches of the individual countries, typically appearing not in isolation, but in connection with certain legal institutions that have already formed (Constantin, 2014, pp. 421-425). It should not be ignored, however, that this is precisely what causes the main difficulties and benefits of public regulation. The wide-ranging regulation associated with legal institutions makes it possible for these legal institutions to be legally enforced only by applying public aspects, but it also makes it difficult to establish the framework for a public and transparent procedure, and perhaps even more importantly, it makes it difficult to maintain and to adapt to changing circumstances. While not excluding each other, the holistic approach through a complete procedure and the above regulatory solution can in any case complicate their relationship necessary to ensure adequate publicity.

The continental regulatory procedure is typically based on this horizontal approach (Vigoda, 2002, pp.527-540), but it should be mentioned in any case that individual legal institutions engage with different weights in setting up the rules and practices resulting in the publicity of the given national administrative proceedings. The difference in weight is due to the fact that the legal institutions to which the branches of the public guarantee system are linked may exert a different influence on the course, lawfulness, and efficiency of the entire administrative proceedings. The initial stages of the procedure, such as clarification of jurisdiction, authority and competences, some details of the client status are of great importance, as the disabilities in them are obviously attributable to the whole proceedings and they may have far-reaching consequences (Kilényi, 2008, p. 1832).

At these critical points of the administrative proceedings, it is extremely important how the individual detailed rules acting towards transparency function as because of the phenomenon of interdependence, the aforementioned high weight of legal institutions places greater emphasis on the rules of the guarantee system at a given point - not to mention the administrative staff carrying out their implementation (Adams \& Balfour, 2014, p. 248).

\section{LIMITATIONS OF ENFORCEMENT OF PUBLICITY}

Looking at the above definitions and basic principles - but in many cases considering the main message of the relevant literature - we could see that transparency is a forward-looking (Armstrong, 2005, pp. 1-10), category of enforcing the rule of law (Bovens et al., 2014, p. 800), which must be assured. Over the past decade, however, there has been an intensification of the view that the extremely important role of transparency and publicity in the legal system has limitations and even some negative effects (Mishiner \& Bersch, 2013, pp. 233-242; Fenster, 2006, pp. 885-950). Most authors mention information security and the protection of personal data generated in the administrative proceedings as a problematic factor, but we can also include some information related to business secrets and copyright areas.

This leads us to the concept of "balance of transparency" (Fenster, 2006, p. 910), which is well characterized by the fact that the publicity of the administrative proceedings must ultimately find an equilibrium position between the disclosure of the necessary information and the release of specified data into unauthorized hands. 


\section{NON-REGULATORY ADMINISTRATIVE COMMUNICATION}

In the context of the chapter related to open communication and the wide-ranging activities of public administration, nonregulatory communication (and hence the activity of integrity advisors in an online environment) plays a very important role in public administration communication. The rules here are much less evident, and this naturally results in the relativity of the subject, the multifaceted implementation and the resulting problems: while there is a procedural framework for regulatory communication - at least regarding its fundamentals and frameworks - which are required to be kept by administrative bodies acting as public authorities, while in the field of non-regulatory communication, these are more of a recommendation or coercive solutions within the constraints of technical infrastructure (Behn, 1995, pp. 313-324) and this is also perfectly true to display information about the integrity management system online.

Accordingly, the requirements of open communication must - or at least should - basically be enforced as outlined in the previous system:

Known roles - This is the least problematic area of public administration communication practice, but it should be noted that there are frequent misrepresentations on the part of the public administration - through its communication channels, it has to find the golden middle between its original role essentially based on sub-super-ordinated administrative relation and its partnership from which a client has to develop an image of a partner-centred administration instead of an organorganizational system which only works on burocratic principles and is far away from society and practical life. The integrity advisor plays a key role in this, possessing essential roles in enhancing organizational transparency.

Appropriate communication interfaces and opportunities - In this area, attention should be paid to two major nodes of change: on the one hand, that officers in the "front office" of the administrative organization system should be aware of the ongoing changes in society and their resulting needs towards the body when communicating with clients (Bencsik et al., 2016, pp. 60-75). On the other hand, there are some expectations towards administration becoming increasingly electronic and cannot be fully understood without it, including on one hand, the establishment and maintenance of electronic availability and suitable platforms (N. Takács,2012), while on the other hand, the creation of an appropriate appearance in the online environment (Józsa, 2013). This is the most important theoretical node of our subject in narrow sense, so we do not analyse its content in detail here.

Confidentiality - The trust of the clients of public administration can only be achieved by fulfilling the trust in the state organization, expectations for the fulfilment of the requirements of the state under the rule of law, and the transparent operation of public administration. This aspect is even more important in an electronic environment (Juhász, 2007, pp. 1730 ), because of the aspects outlined in open communication. It is important that the maintenance of proper trust should not change into confidentiality, and the body should properly handle its role towards the client. The clear task of the integrity advisor with both internal and external actors is to create and maintain appropriate trust, and in this respect, the electronic path is of paramount importance, as outlined above.

Interpretability, clarity, and consistency (Bozeman \& Bretschneider, 1994, pp. 197-224) - The complex operation of the administration, which is often pervaded by complicated professional language phrases, makes it difficult to communicate organizational activity, which is, however, an essential condition for transparent operation. Accordingly, when using any communication channel, the public administration body should always seek clarity and limitations of the recipient's interpretation possibilities. It also includes not being misleading in communication and the nature of the service should pervade its communication.

\section{References}

[1] Adams, G., \& Balfour, D. (2014). Unmasking administrative evil. London, Routledge. p. 248.

[2] Akaike, H. (1998). Information theory and an extension of the maximum likelihood principle. In: Selected papers of hirotugu akaike. Springer, New York, pp. 199-213.

[3] Armstrong, E. (2005). Integrity, transparency and accountability in public administration: Recent trends, regional and international developments and emerging issues. United Nations, Department of Economic and Social Affairs. pp. 1-10.

[4] Atouba, Y. C., Carlson, E. J., \& Lammers, J. C. (2016). Directives and dialogue: Examining the relationship between participative organizational communication practices and organizational identification among IT workers. International Journal of Business Communication. 
[5] Becker, T. E. (1998). Integrity in Organizations: Honesty and Conscientiousness. Academy of Management Review,, pp. 154-161.

[6] Behn, R. D. (1995). The big questions of public management. Public Administration Review, pp. 313-324.

[7] Bellamy, C., \& Taylor, J. (1992). Informatisation and new public management: an alternative agenda for public administration. Public Policy and Administration, 7(3), pp. 29-41.

[8] Belényesi, E. (2012). Az elektronikus közigazgatás és a változásmenedzsment (The e-public administration and the management of changes). Új Magyar Közigazgatás (New Hungarian Public Administration), 5(5), pp. 30-36.

[9] Bencsik, A., Fábián, A., Pál, E., \& Szőke, G. L. (2016). A közigazgatás és a média kapcsolódási pontjai. Pro Publico Bono-Magyar Közigazgatás, (4), pp. 60-75.

[10] Bertot, J. C., Jaeger, P. T., \& Grimes, J. M. (2010). Using ICTs to create a culture of transparency: E-government and social media as openness and anti-corruption tools for societies. Government information quarterly, 27(3), pp. 264-271

[11] Bertot, J. C., Jaeger, P. T., \& Hansen, D. (2012). The impact of polices on government social media usage: Issues, challenges, and recommendations. Government information quarterly, 29(1), pp. 30-40.

[12] Bingham, L. B., \& Nabatchi, T., O'Leary, R. (2005). The new governance: Practices and processes for stakeholder and citizen participation in the work of government. Public Administration Review 65(5), pp. 547558.

[13] Bovens, M., \& Goodin, R. E., Schillemans, T. (2014). The Oxford handbook of public accountability. Oxford, Oxford University Press. p. 800.

[14] Bozeman, B., \& Bretschneider, S. (1994). The "publicness puzzle" in organization theory: A test of alternative explanations of differences between public and private organizations. Journal of Public Administration Research and Theory, 4(2), pp. 197-224.

[15] Braun, S., Bark, A. H., Kirchner, A., Stegmann, S., \& Dick, R. van. (2018). Emails From the Boss-Curse or Blessing? Relations Between Communication Channels, Leader Evaluation, and Employees' Attitudes. International Journal of Business Communication, 56(1), pp. 50-81.

[16] Butler, J. K., \& Cantrell, R. S. (1984) A behavioral decision theory approach to modeling dyadic trust in superiors and subordinates. Psychological Reports, 1984, 55(1) pp. 19-28.

[17] Chen, C. P., \& Zhang, C. Y. (2014). Data-intensive applications, challenges, techniques and technologies: A survey on Big Data. Information Sciences, 275, pp. 314-347.

[18] Clarke, A., \& Margetts, H. (2014). Governments and citizens getting to know each other? Open, closed, and big data in public management reform. Policy \& Internet, 6(4), pp. 393-417.

[19] Constatin, E. (2014). The Principle of Transparency in Administrative Law. Contemporary Readings in Law and Social Justice 6(1). pp. 421-425.

[20] Cover, T. M., \& Thomas, J. A. (2012). Elements of information theory. John Wiley \& Sons, New York.

[21] De Nicola, A., Villani, M. L., Brugnoli, M. C., \& D'Agostino, G. (2016). A methodology for modeling and measuring interdependencies of information and communications systems used for public administration and eGovernment services. International Journal of Critical Infrastructure Protection, 14, pp. 18-27.

[22] Denhardt, R. B., \& Denhardt, J. V. (2000). The new public service: Serving rather than steering. Public administration review, 60(6), pp. 549-559.

[23] Doornbos, M. (2001). Good governance': The rise and decline of a policy metaphor?. Journal of Development Studies 37(6), pp. 93-108.

[24] Durant, R. F., \& Durant, J. R. (Eds.). (2017). Debating Public Administration: Management challenges, choices, and opportunities. Routledge. pp. 120-150.

[25] Fábián, A. (2016). Közigazgatás elmélet (Theory of public administration). Budapest-Pécs, Dialóg Campus Publisher. pp. 25-45.

[26] Fenster, M. (2006). The opacity of transparency. lowa Law Review, 91(3), pp. 885-950.

[27] Frederickson, H. G., \& Rohr, J. A. (2015). Ethics and public administration. New York, Routledge, pp. 25-55.

[28] Gray, R. M. (2011). Entropy and information theory. Springer Science \& Business Media.

[29] Groves, P., Kayyali, B., Knott, D., \& Van Kuiken, S. (2013). The 'big data'revolution in healthcare. McKinsey Quarterly, 2(3).

[30] Henry, N. (2017). Public administration and public affairs. New York-London, Routledge. pp. 80-92. 
[31] Hohmann, B. (2018). A hatósági eljárás társadalmi ellenőrzésének lehetőségei. Tudatosan a Környezetünkért Egyesület pp. 7-9.

[32] Hood, C. (1991). A public management for all seasons?. Public Administration, 69(1), pp. 3-19.

[33] Hosmer, L. T. (1995). Trust: The connecting link between organizational theory and philosophical ethics. Academy of Management Review, 20(1) pp. 379-403.

[34] Ivancsics, I., Fábián, A. (2018). Hatósági jogalkalmazás a közigazgatásban (Administrative law application in the public administration). Budapest-Pécs, Dialóg Campus Publisher, pp. 32-54.

[35] Józsa, V. (2013). Egy közigazgatási szerv kommunikációs stratégiája (Strategy of the administrative agencies). Nemzeti Közszolgálati Egyetem (National Public Service University), Budapest.

[36] Juhász, L. (2007). E-közigazgatás Európában: fókuszban a közigazgatás racionalizálása és az állampolgár. (Epublic administration in Europe: The rationalization of public administration and the citizen on the focus). Információs Társadalom (Information Society) 7(1), pp. 17-30.

[37] Karanges, E., Johnston, K., Beatson, A., \& Lings, I. (2015). The influence of internal communication on employee engagement: A pilot study. Public Relations Review, 41(1), pp. 129-131.

[38] Kettl, D. F. (2015). The transformation of governance: Public administration for the twenty-first century. Baltimore, Johns Hopkins University Press. 240. p.

[39] Kilényi, Géza (szerk.) (2008). A közigazgatási jog nagy kézikönyve (The Handbook of Administrative Law). Budapest, Complex Kiadó. p. 1832.

[40] King, C. S., Feltey, K. M., \& Susel, B. O. N. (1998). The question of participation: Toward authentic public participation in public administration. Public Administration Review, pp. 317-326.

[41] Kim, G. H., Trimi, S., \& Chung, J. H. (2014). Big-data applications in the government sector. Communications of the $A C M, 57(3)$, pp. 78-85.

[42] Kramer, M. W. (2014). Managing uncertainty in organizational communication. New York, Routledge. pp. 33-50

[43] Kuhn, T., Ashcraft, K. L., \& Cooren, F. (2018). What Work Can Organizational Communication Do?. Management Communication Quarterly I-II.

[44] Lan, Z., Rosenbloom, D. H. (1992). Editorial: public administration in transition?. Public Administration Review, 52(6), pp. 535-537.

[45] L. László, J., \& Vég, O. (2004). Sms-technológia a közigazgatás és a köz szolgálatában. (SMS-technology in the public adminstration and the public service) Médiakutató (Median Researches), pp. 1-16.

[46] Lavertu, S. (2016). We all need help:"Big data" and the mismeasure of public administration. Public administration review, 76(6), pp. 864-872.

[47] Ljungholm, D. P. (2015). The impact of transparency in enhancing public sector performance. Contemporary Readings in Law and Social Justice, 7(1), p. 172.

[48] Lourenço, R. P. (2015). An analysis of open government portals: A perspective of transparency for accountability. Government Information Quarterly, 32(3), 323-332.

[49] Menzel, D. C. (2015). Research on ethics and integrity in public administration: Moving forward, looking back. Public Integrity, 17(4), pp. 343-370.

[50] Meijer, A. (2013). Understanding the complex dynamics of transparency. Public Administration Review, 73(3), pp. 429-439.

[51] Middleton, K. R., Lee, W. E., \& Stewart, D. (2017). The Law of Public Communication. New York, Routledge. pp. 105-140.

[52] Michener, G., \& Bersch, K. (2013). Identifying transparency. Information Polity, 18(3). pp. 233-242.

[53] N. Takács, V. (2012). A közigazgatási informatikai rendszerek fejlesztésével kapcsolatos felhasználói elvárások. Hadmérnök, 7(4).

[54] Nabatchi, T. (2012). Putting the "public" back in public values research: Designing participation to identify and respond to values. Public Administration Review, 72(5), pp. 699-708.

[55] Nisbet, M. C. (2009). Communicating climate change: Why frames matter for public engagement. Environment: Science and policy for sustainable development, 51(2), pp. 12-23.

[56] Ostrom, V., \& Ostrom, E. (1971). Public choice: A different approach to the study of public administration. Public Administration Review, 31(2), pp. 203-216.

[57] Ricciardi, F., Harfouche, A., \& Ricciardi. (2016). Information and Communication Technologies in Organizations and Society. Switzerland, Springer International Publishing. pp. 51-71. 
[58] Rhodes, R. A. (2016). Recovering the craft of public administration. Public Administration Review, 76(4), pp. 638-647.

[59] Rhodes, R. A. (2000). Governance and public administration. Debating governance, 54, p. 7.

[60] Roblyer, M. D., McDaniel, M., Webb, M., Herman, J., \& Witty, J. V. (2010). Findings on Facebook in higher education: A comparison of college faculty and student uses and perceptions of social networking sites. The Internet and higher education, 13(3), pp. 134-140.

[61] Rosenbloom, D. H., Goldman, D. D. (1993). Public administration: Understanding management, politics, and law in the public sector. New York, McGraw-Hill.

[62] Venkatesh, V., Thong, J. Y., Chan, F. K., \& Hu, P. J. (2016). Managing citizens' uncertainty in e-government services: The mediating and moderating roles of transparency and trust. Information Systems Research, 27(1), pp. 87-111.

[63] Vigoda, E. (2002). From responsiveness to collaboration: Governance, citizens, and the next generation of public administration. Public Administration Review, 62(5), pp. 527-540.

[64] Von Haldenwang, C. (2004). Electronic government (e-government) and development. The European Journal of Development Research, 16(2), pp. 417-432.

[65] Wirtz, B. W., Weyerer, J. C., \& Rösch, M. (2017). Open government and citizen participation: an empirical analysis of citizen expectancy towards open government data. International Review of Administrative Sciences, pp. 1-21. 